\title{
Neurogenetics and Human Consciousness
}

\section{John K Grandy*}

North Country Urgent Care, Watertown, New York, USA

Human consciousness has historically been an enigma tantalizingly engaged by philosophy. However, the topic of human consciousness was confronted by psychology in the later part of the 1800's, most notably by William James [1]. In due course, a framework of consciousness based on the neural correlates of consciousness (NCC) was proposed by Francis Crick and Christof Koch in 2003 [2]. In this framework brain systems are active in tandem with the conscious experience.

Eventually, a more profound and clandestine phenomenon would be proposed to account for the emergence of human consciousnessDNA consciousness, which was proposed in two previous works in $2006[3,4]$. The theory of DNA consciousness proposes that the DNA molecule gives rise to human consciousness and that DNA possesses a degree of consciousness in its own right [5]. Recently, the theory of DNA consciousness has evolved into three neurogenetic phases of human consciousness [6]. In this framework neurogenetic correlates of consciousness $(\mathrm{NgCC})$ function on an underlying scale in relationship to any NCC. In this paradigm NgCC are involved in the emergence, the continuum, and the decline of human consciousness (typically caused by neurodegeneration) i.e. the three neurogenetic phases of human consciousness.

Each of the three neurogenetic phases possesses hundreds, and perhaps thousands, of genes (and gene products) that are pivotal to human consciousness. An early conceptualization and organization of some of these genes and their place in the three neurogenetic phases of human consciousness has been proposed [7]. Some of these genes are involved in more than one neurogenetic phase.

The first neurogenetic phase is the emergence of neuron-based consciousness. The processes involved in brain morphogenesis and the emergence of the central nervous system requires the strict regulation by master genes and trans-activation throughout the developmental hierarchy. This allows undifferentiated progenitor cells to flourish into cells with a specific function and ultimately compartmentalize into specific regions of the brain that become the primary machinery of human consciousness. Certain families of genes are absolutely necessary for these brain regions to come forth to fruition. The following genes are examples of $\mathrm{NgCC}$ but by no means a complete enumeration.

The Pax3 gene is required early in embryogenesis [8] and is required for neural tube development and closure [9]; which is the early foundations of the human brain and nervous system. The Pax3 is also responsible for the regulation of the expression of Hes1 and Neurog2 which are important to neuronal stem cell maintenance and the neuronal subtypes [10]; as well as the regulation of the expression of Meis2 which is pivotal for the formation of the tectum [11].

The Pax6 gene is a master regulator of eye development and is highly conserved throughout the animal kingdom [12]. One of the ways Pax6 is critical to eye development is by controlling lens formation. This is accomplished by regulating the expression of four other genes L-maf, Sox1, Prox-1, and lens structural protein crystallins $\alpha, \beta$, and $\gamma$ [13]. In addition, Pax6 is involved in the neurogenetic fates of the glial progenitor cell in the forebrain [14], the proper development of thalamocortical connections [15], and the regulation of neurogenesis of neuron-glia2 progenitor cells in the hippocampus [16].

The Hox genes are important determinants of the anteroposterior
(AP) patterning of all embryos throughout the animal kingdom [17]. However, several Hox genes also control brain morphogenesis. Otx1 and Otx 2 are Hox genes that have been shown to be expressed in the human brain during weeks 7-14 [18], and both genes are required for the full development of the thalamus; particularly the zona limitan intralamica [19]. In addition, Otx1 is critical for the formation of the neocortex and for the overall development of the cerebral cortex [18]; and Otx2 is critical for the formation of the diencephalon and hippocampal anlage [18]. Other examples of Hox genes that are involved in brain morphogenesis are Hoxd4 and Hoxb4, which are neural enhancers that enforce the border of the anterior brain and rhombomeres 6 and 7 in the hind brain [20,21].

Using only six genes as examples, it can be visualized that these $\mathrm{NgCC}$ have a profound impact on the emergence and proper functional development of the brain, which will ultimately become the primary machinery involved in experiencing human consciousness in the physical world.

The second neurogenetic phase is the continuum of neuron-based consciousness. Several genetic abnormalities can alter this continuum. This can be illustrated by observing the genetic association of several psychiatric disorders that clinically demonstrate disruptions in thought, perception, volition, and interaction with the external environment.

PTCHD1 locus disruptions have been associated with Autism disorder [22,23]. Autism is a disorder characterized by observable deficits in communication, socialization, and reciprocal interactions.

Schizophrenia is a disorder of thought and volition, which is clinically characterized by profound emotional and cognitive disturbances, and often concomitant with defects in cortical activity and hallucinations. Abnormal expression of schizophrenia-associated genes PDE4B [24] and DISC1 [25] have both demonstrated a strong association to schizophrenia. The transcription factor ZNF804a has also been correlated with schizophrenia. This is likely due to the fact that ZNF804a regulates the expression of several schizophrenia-associated genes e.g. PRSS16, COMT, PDE4B, and DRD2 [26].

The continuum of human consciousness requires that neurons in the brain have the ability to change and form new connections in response to new information and stimuli. Therefore, neuron plasticity is an essential feature of human consciousness. BDNF gene is a potent modulator of synaptic plasticity [27]. BDNF is also involved in the maturation of the prefrontal cortex and the hippocampus, and is involved in memory and learning [28]. Polymorphisms in BDNF have

*Corresponding author: John K Grandy, North Country Urgent Care, Watertown New York, USA, Tel (315) 786-3436; E-mail: khyber_john@yahoo.com

Received January 16, 2014; Accepted January 18, 2014; Published January 23 2014

Citation: Grandy JK (2014) Neurogenetics and Human Consciousness. J Neurol Disord 2: e109. doi:10.4172/2329-6895.1000e109

Copyright: (c) 2014 Grandy JK. This is an open-access article distributed under the terms of the Creative Commons Attribution License, which permits unrestricted use, distribution, and reproduction in any medium, provided the original author and source are credited. 
been associated with decreased modulation of hippocampal plasticity [29]. The FGF2 gene has also demonstrated involvement in the maintenance of neuron plasticity during adulthood [30]. FGF2 is also involved in the proliferation of hippocampal neuron progenitor cells status post traumatic brain injury [31].

The $\Delta \mathrm{FosB}$ transcription factor, a truncated splice variant of FosB, can be induced by drugs of abuse. While it is induced it can alter the expression of four other genes- GluR2, Cdk5, NFкB, and Dynorphin, which can cause neuroplastic-related morphological changes in the brain and decreases in the connectivity of some of the white matter tracts [32]. These changes can contribute to the clinical syndromes opioid- induced hyperalgesia and hyperkatifeia [33].

With just these few examples we see that genetic pathways can have a significant impact on the continuum of human consciousness during adulthood and abnormalities in pivotal genes can have observable effects that can be manifested as psychiatric disorders and neurological disorders related to neuron plasticity. These disorders can be objectified clinically.

The third neurogenetic phase is neurodegeneration or the erosion of some of the modalities of neuron-based consciousness. This is exemplified very well in Alzheimer disease in which cognitive skills, behavioral abnormalities, and memory loss are common ailments. In 2011, the guidelines for diagnosing Alzheimer disease where updated and this neurodegenerative disease is now recognized in three phases [34]. During the dementia phase of Alzheimer disease a decrease in the degrees of human consciousness is seen i.e. the patient ceases to be whom they once were.

An overwhelming amount of evidence has implicated several genetic pathways in Alzheimer disease. Four genes in particularAPP, PSEN1, PSEN2, and APOE- $\varepsilon 4$ have been correlated with this neurological disorder and there is strong hope that affordable and reliable genetic tests may emerge to screen for susceptibility [35]. Early detection may be important as some patients with APOE- $\varepsilon 4$ phenotype have been shown to benefit from the oral administration of melatonin while in the mild cognitive impairment phase of Alzheimer disease [36]. This could be due in part to the fact that melatonin is involved in genetic pathways that counteracts the activity of free radicals and enhances DNA repair by its effect on $>100$ genes [37].

By studying genes associated with Alzheimer disease NgCC are identified, that when those genes do not function properly (due to mutations), and demonstrate a decline in the global functioning of human consciousness. In previous works I have attempted to use these motifs to make a scientific connection between the phenomenon of Alzheimer disease and DNA consciousness [38].

In conclusion, what I have established at this juncture is a starting point in enumerating several $\mathrm{NgCC}$. Hence much more research needs to be completed in order to make the importance of the genetic pathways in which the NgCC serve to function in the three respective neurogenetic phases of human consciousness. However, as of now a feasible proposal has been put forth; a paradigm which may redefine how we understand human consciousness. This could also change the way in which we view DNA- from a mere genetic storage unit to a dynamic entity with a degree of consciousness that has already been scientifically objectified on three dynamic levels [39].

\section{References}

1. William J (1890) The Principles of Psychology. Introduction by George A. Miller, Harvard University Press.
2. Crick F, Koch C (2003) A framework for consciousness. Nat Neurosci 6: 119 126.

3. Grandy J (2006) Consciousness. In: The Encyclopedia of Anthropology. Sage Publications, Inc. Thousand Oaks, California.

4. Grandy J (2006) DNA Molecule. In: The Encyclopedia of Anthropology. Sage Publications, Inc. Thousand Oaks, California.

5. Grandy J (2011) The DNA molecule is autopoietic, dynamic, evolving, and a form of consciousness. The International Journal of Arts and Sciences 4: 7-28.

6. Grandy J (2013) The Neurogenetic Correlates of Consciousness. In: The Physics of Reality: Space, Time, Matter, Cosmos, 8th Symposium in honor of Jean-Pierre Vigier Edited by: R.L. Amoroso, L.H. Kauffman, \& P. Rowlands.

7. Grandy J (2013) The Three Neurogenetic Phases of Human Consciousness Journal of Conscious Evolution 9: 1-24.

8. Goulding MD, Chalepakis G, Deutsch U, Erselius JR, Gruss P (1991) Pax3 , a novel murine DNA binding protein expressed during early neurogenesis. EMBO J 10: 1135-1147.

9. Wang XD, Morgan SC, Loeken MR (2011) Pax3 stimulates p53 ubiquitination and degradation independent of transcription. PLoS One 6: e29379.

10. Ichi S, Boshnjaku V, Shen YW, Mania-Farnell B, Ahlgren S, et al. (2011) Role of Pax3 acetylation in the regulation of Hes1 and Neurog2. Mol Biol Cell 22 503-512.

11. Agoston Z, Schulte D (2009) Meis2 competes with the Groucho co-repressor Tle4 for binding to Otx2 and specifies tectal fate without induction of a secondary mid-hindbrain boundary organizer. Development 136: 3311-3322.

12. Callaerts P, Halder G, Gehring WJ (1997) PAX-6 in development and evolution Annu Rev Neurosci 20: 483-532.

13. Quiring R, Walldorf U, Kloter U, Gehring WJ (1994) Homology of the eyeless gene of Drosophila to the Small eye gene in mice and Aniridia in humans. Science 265: 785-789.

14. Jang ES, Goldman JE (2011) Pax6 Expression is Sufficient to Induce a Neurogenic Fate in Glial Progenitors of the Neonatal Subventricular Zone. PloS ONE 6: e20894.

15. Wang L, Bluske KK, Dickel LK, Nakagawa Y (2011) Basal progenitor cells in the embryonic mouse thalamus - their molecular characterization and the role of neurogenins and Pax6. Neural Dev 6: 35.

16. Klempin F, Marr RA, Peterson DA (2012) Modification of pax6 and olig2 expression in adult hippocampal neurogenesis selectively induces stem cell fate and alters both neuronal and glial populations. Stem Cells 30: 500-509.

17. Gilbert S (2013) Developmental Biology, (10th edn) Sunderland (MA) Sinauer Associates.

18. Larsen KB, Lutterodt MC, Møllgård K, Møller M (2010) Expression of the Homeobox Genes OTX2 and OTX1 in the early developing human brain. $J$ Histochem Cytochem 58: 669-678.

19. Scholpp S, Foucher I, Staudt N, Peukert D, Lumsden A, et al. (2007). Otx1I, Otx2, and Irx1b establish and position the ZLI in the diencephalon. Development 134: $3167-3176$

20. Serpente P, Tümpel S, Ghyselinck NB, Niederreither K, Wiedemann LM, et al (2005) Direct cross regulation between retinoic acid receptor $B$ and Hox genes during hindbrain segmentation. Development 132: 503-513.

21. Rastegar M, Kobrossy L, Kovacs EN, Rambaldi I, Featherstone M (2004) Sequential Histone Modifications at Hoxd4 Regulatory Regions Distinguish Anterior from Posterior Embryonic Compartments. Mol Cell Biol 24: 8090-8103.

22. Noor A, Whibley A, Marshall CR, Gianakopoulos PJ, Piton A, et al. (2010) Disruption at the PTCHD1 locus on Xp22.11 in autism spectrum disorder and intellectual disability. Sci Transl Med 2: 49ra68.

23. Filges I, Röthlisberger B, Blattner A, Boesch N, Demougin $P$, et al. (2011) Deletion in Xp22.11: PTCHD1 is a candidate gene for X-linked intellectual disability with or without autism. Clin Genet 79: 79-85.

24. Guan F, Zhang C, Wei S, Zhang H, Gong X, et al. (2012) Association of PDE4B polymorphisms and schizophrenia in Northwestern Han Chinese. Hum Genet 131: 1047-1056.

25. Bradshaw NJ, Porteous DJ (2012) DISC1-binding proteins in neura development, signaling and schizophrenia. Neuropharmacology 62: 1230-1241. 
26. Girgenti MJ, LoTurco JJ, Maher BJ (2012) ZNF804a regulates expression of the schizophrenia-associated genes PRSS16, COMT, PDE4B, and DRD2. PLoS One 7: e32404.

27. Cowansage KK, LeDoux JE, Monfils MH (2010) Brain-derived neurotrophic factor: a dynamic gaterkeeper of neural plasticity. Curr Mol Pharmacol 3: 12-29.

28. Binder DK, Scharfman HE (2004) Brain-derived Neurotrophic Factor. Growth Factors 22: 123-131.

29. Egan MF, Kojima M, Callicott JH, Goldberg TE, Kolachana BS, et al. (2003) The BDNF val66met Polymorphism Affects Activity-Dependent Secretion of BDNF and Human Memory and Hippocampal Function. Cell 112: 257-269.

30. Zechel S, Werner S, Unsicker K, und Halbach OB (2010) Expression and functions of fibroblast growth factor 2 (FGF-2) in hippocampal formation. Neuroscientist 16: 357-373.

31. Yoshimura S, Takagi Y, Harada J, Teramoto T, Thomas SS, et al. (2001) FGF2 regulation of neurogenesis in adult hippocampus after brain injury. PNAS 98 : 5874-5879.

32. Grandy J (2013) Molecular Genetic Mechanisms of Addition Involving the $\triangle$ FosB pathways. A chapter in Marie Clare Van Hout's book: Drug Use and
Abuse: Signs/symptoms, physical and psychological Effects and Intervention Approaches. Nova Publications.

33. Grandy J (2012) A Clinical Correlation Made Between Opioid-induced Hyperalgesia and Hyperkatifeia with Brain Alterations Induced by Long-term Prescription Opioid Use. Research \& Reviews: A Journal of Neuroscience 2 : $1-11$.

34. Grandy JK (2012) Updated guidelines for the diagnosis of Alzheimer disease: a clinical review. JAAPA 25: 50-55.

35. Grandy J (2011) Biomarkers and gene mutations as aids for detecting AD early. Journal of the American Academy of Physician Assistants 24: 56-57.

36. Grandy J (2013) Melatonin: Therapeutic Intervention in Mild Cognitive Impairment and Alzheimer Disease. J Neurol Neurophysiol 4: 148.

37. Liu R, Fu A, Hoffman AE, Zheng T, Zhu Y (2013) Melatonin enhances DNA repair capacity possibly by affecting genes involved in DNA damage responsive pathways. BMC Cell Biol 14: 1.

38. Grandy J (2012) Alzheimer Disease and DNA Consciousness. Academic Journal of Science 1: 169-184.

39. Grandy J (2013) The Three Dynamic Levels of DNA Consciousness. The International Journal of Arts and Sciences 6: 313-327. 